\title{
Regionalism versus Multilateralism: Evidence for the Natural Trade Partners Theory from the Euro-Mediterranean Region?
}

\author{
Yener Kandogan \\ University of Michigan-Flint
}

\begin{abstract}
The slow pace of multilateral negotiations has given a greater impetus to regional trade arrangements (RTA) as countries are eager to take advantage of welfare enhancing trade creation effect of trade liberalization. At the same time, this approach raises concerns as due their discriminatory nature, RTAs lead to welfare reducing trade diversion from third countries. The paper develops a modified triple-indexed gravity model to measure the trade creation and diversion effects of the preferential trade agreements in the Euro-Mediterranean region. The model is applied to different components of imports, since the welfare implications of each component is expected to be different. Using these measures, the paper proceeds to look for evidence for the Natural Trade Partners Theory using three definitions of natural partners. Results show that there is support for the theory when geographical distance or initial trade volumes are used to define naturalness only for intra-industry components. Stronger support is found when complementarity is used to identify natural partners.
\end{abstract}

- JEL classification: F14, F15

- Keywords: Trade creation and diversion, Triple-indexed gravity model, Trade blocs, Intra-industry trade

\footnotetext{
*Corresponding address: Yener Kandogan, School of Management University of Michigan-Flint 303 E. Kearsley Flint, MI 48502. Tel: (810) 237 6675, Fax: (810) 762 3282, E-mail: yener@umich.edu

@ 2008-Center for International Economics, Sejong Institution, All Rights Reserved.
} 


\section{Introduction}

Since Viner (1950), it is known that the impact of any trade liberalization effort, unless multilateral, is a combination of trade creation and trade diversion effects. While the former effect has welfare gain implications for both partners involved, the latter reduces the importer country's welfare. In multilateral liberalizations have a non-discriminatory approach, and all countries are treated equally. This ensures economic benefits from trade creation for all countries. Therefore, there is no danger that trade would be diverted from an efficient third country producer to less efficient partners as a result of reductions in trade barriers. This is the idea behind the World Trade Organization (WTO) rule that each member accord Most Favored Nation (MFN) status to other WTO members.

The WTO allows exceptions to the MFN principle for RTAs as long as trade barriers against third countries are not raised. Countries have been taking the route of regional trade arrangements (RTA) in response to slow pace of the multilateral negotiations. The desire for RTAs is further exacerbated after two failed round of negotiations in Seattle and Doha. While there were 124 RTA notifications to the WTO from 1948 to 1994, since 1995 more than 130 additional such arrangements have been created.

This approach raised concerns among prominent economists such as Bhagwati. He has spoken out on this issue before the US Congress:

"The great economics who warned us against preferences during the 1930s, when competitive tariff-raising was creating fragmented markets worldwide, would have been horrified to see that, in the name of free trade, we are now reenacting such fragmented markets on a parallel scale, and feeling virtuous about it."

The Natural Trade Partners Theory is a result of attempts to identify characteristics that lead to more creation than diversion, thus ensure net welfare gains as a result of RTAs. The central statement of the theory is that trade agreements with regional countries is less likely to be trade diverting and therefore geographically close partners are natural partners.

Although a quick scrutiny of the liberalization agreements will show that the suggestions of the Natural Trade Partners Theory has been taken whole-heartedly by countries around the World ${ }^{1}$, empirical tests repeatedly failed to find significant

${ }^{1}$ See "Free Trade Areas: An Appraisal", a 1995 communication from the EU Commission to the EU Council. 
evidence for it. $^{2}$ Most recently, Krishna (2003) examines this theory using the US data, but fails to find correlation between distance and his welfare estimates. Given the physical size of the US, and its relative geographical isolation from the rest of the World, this result is not very surprising. In this paper, this theory is once again tested using a gravity model applied to the trade of 42 relatively smaller countries in the Euro-Mediterranean region that are in close proximity to each other.

Until now, gravity modelers rarely tried to decompose these trade creation and diversion effects of trade agreements (Greenaway and Milner, 2002). Some tried to use dummy variables for each agreement for this purpose. That approach was criticized by Polak (1996) as such variables may lead to incorrect inferences. Separately, Matyas (1997) shows that all gravity models used so far to account for effects of liberalization agreements are actually mis-specified from the econometric point of view due to presence of unnecessary constraints put on the parameters of the model. Taking these criticisms into account, this paper develops a methodology to decompose trade creation and diversion effects using the parameters of a correctly-specified gravity model that does not use dummy variables to represent trade agreements.

Expanding Matyas' suggestion of removing constraints on the parameters, the gravity model developed in this paper is for different components of trade, rather than overall trade. Thus intra-industry, vertical and horizontal intra-industry components of trade in different sectors are allowed to have different parameters. This is important in the framework of this paper, given different implications of each component on trade creation and diversion.

The rest of the paper is organized as follows: Section II briefly surveys the literature on the theory of natural trade partners. After discussing the recent econometric developments in gravity modeling, a correctly specified gravity model and a methodology to decompose trade creation and diversion effects are proposed in Section III along with a justification for considering different components of trade separately. These are applied to the trade in the Euro-Mediterranean region in Section IV with a discussion of the policy implications of the results for the Natural Trade Partners Theory.

${ }^{2}$ Frankel (1996) is a partial exception, since he finds distance as a significant determinant of trade flows. However, in this gravity model, no attempt is made to estimate trade creation and diversion. 


\section{Background on Theory of Natural Trade Partners}

All efforts to liberalize trade lead to welfare-improving trade creation: The removal of trade barriers leads to elimination of domestic sourcing by firms and consumers in some industries in favor of imports that are more efficiently produced in other countries. However, Viner (1950) established that preferential liberalizations as opposed to unilateral liberalizations also give rise to trade diversion. This is due to the discriminating nature of preferential liberalization agreements since specific partner countries are favored. The removal of trade barriers for partner countries may lead firms and consumers to source from less efficient suppliers located in a partner country rather than from the least cost source of supply, hence reducing the welfare of the importer country.

Since then, economists tried to refine the theory in an attempt to determine characteristics of member countries and those of liberalization agreements that would ensure welfare improvements. As Panagariya (1997) notes, much of the earlier work on this topic such as Meade (1955), Lipsey (1960), Johnson (1962), and later somewhat synthesized by McMillan and McCann (1981) yielded results that are mostly taxonomic and not practically applicable.

More recently, renewed interest in the literature suggested a rather simple criterion of natural trading partners. This Natural Trade Partners Theory suggests that liberalization of trade with natural trading partners is more likely to be trade creating among partners and less likely to divert trade from non-partners. While Wonnacott and Lutz (1989) and Summers (1991) define natural partners as countries with high initial trade volume, Krugman (1991) and Frankel et al. (1995) propose geographical proximity to define natural trading partners. Deardorff and Stern (1994) also make a similar point that lower transport costs increases the benefits of preferential liberalizations. However, Bhagwati and Panagariya (1996) find both definitions untenable citing the loss of tariff revenue as the reason for the former definition, and significant similarity for the latter. In contrast to the Natural Trade Partners Theory's predictions, Panagariya (1997) suggests that the larger the initial level of trade between the partners or the closer they are geographically, the more they will lose from a preferential trading agreement. Similar arguments are also made by Schiff (1997).

Later, Schiff (1999) argues that neither side is completely correct. He proposes that definition of natural trading partners should be changed to complement countries, where one tends to import what the other exports to maintain the 
theory's predictions.

Although the vast majority of the liberalizations in the World has been regional, in other words between countries that can be called natural partners according to different definitions of naturalness, empirical tests of this theory repeatedly failed to find significant evidence for the theory. Most recently, Krishna (2003) computed the correlation of welfare estimates with the trade volume and distance, and found no correlation of the estimates with either.

Given the relatively large size of the US, and its relatively distant location from the rest of the World, this result is not very surprising. A geographically large country with multiples of important economic centers makes computation of distance between partner countries' centers complicated and leads to errors in measurement. Furthermore, when distances to different countries are all very large, small differences in distance becomes insignificant. Both of these complications make geographic location a less important factor in determining welfare effects, and consequently resulting in the Natural Trade Partners Theory without strong evidence. Therefore, the methodology developed in this paper to capture trade creation and diversion effects is applied to the trade of 42 relatively smaller countries in the EuroMediterranean region. Typically these countries have one economic center, and the distances to partners' centers vary significantly.

The resulting measures of creation and diversion for these countries are analyzed to see if there is evidence for the theory, and if there is, which definition of naturalness works. Is it high initial trade volumes, geographical proximity, or complementarity between two countries that tends to lead to more trade creation and less trade diversion?

In such an analysis, some other factors that lead to variation in creation and diversion should be controlled for to get more clear impact of what makes two partners natural.

Initial tariff rates before liberalization and the tariff rates facing the non-partners after liberalization could be different across countries. These would lead to trade creation and diversion of different magnitudes (Hoekman and Djankov, 1996). Competitiveness of both partners and non-partners is also another factor to take into account. Other things being equal, if the partners are competitive, there will be less trade diversion, whereas diversion will be larger if the non-partners are competitive.

Lastly, not all preferential agreements have the same effect. There are numerous reasons for different impacts: The intensity of the agreement could be different. For 
example, a customs union adopts a common external tariff structure in addition to a free trade area. The degree of implementation could be different. Trade in some sectors could be left out after calling them sensitive (Mathilde and Cheikbossian, 1998). The rate of liberalization on each partner's side could be different and asymmetric (Alessandri, 2000). For instance, the Mediterranean Cooperation Agreements merely opened the European markets to Mediterranean producers, where reciprocity was not required, as it was later in the Euro-Mediterranean Agreements.

\section{The Approach}

\section{A. Developments in gravity modeling}

Since its development by Tinbergen (1962), Poyhonen (1963) and Linneman (1966), the gravity model has significantly changed. In its simplest form, the volume of bilateral trade between two countries is explained by the size of their economy, and the geographical distance between their economic centers. This basic model has been augmented by monetary variables such as exchange rate and GDP deflator (Bergstrand, 1985) or more directly by the real exchange rate (Bayoumi and Eichengreen, 1995), and measures of exchange rate uncertainty as suggested by Thursby and Thursby (1987) such as foreign currency reserves (Matyas, 1997). Variables coming from competing trade theories are also often added to the model. Measures of relative factor endowments as suggested by the Heckscher-Ohlin Theory, and measures of similarity as suggested by the Increasing Returns Theory can be found in gravity models of Balassa (1986), Helpman (1987), and Balassa and Bauwens (1987). Other trade-promoting variables that capture different aspects of bilateral relations also often find their way into gravity models. Common border, common language, past colonial relations and measures of cultural proximity can be counted as the most frequently considered additions.

These gravity models are typically used to test the significance of preferential agreements on trade volumes with the help of bloc dummy variables. Positive and significant coefficients for these bloc variables are interpreted as trade promoting effects of these agreements among its participants in comparison to third countries. Raising econometric issues, Polak (1996) criticizes such use of bloc dummy variables directly in gravity models as they may lead to incorrect inferences.

Some other econometric problems about the specification in the gravity models 
have also been recently raised. Wang and Winters (1991) argued against averaging models' variables over time since that would restrict the parameters of the model to be the same for every year. Similarly, Baldwin (1994) argued that using total trade as the dependent variable imposes an unnecessary constraint of equal coefficients for imports and exports. Matyas (1997) took this idea further to suggest that a correctly specified model should have separate constants not only for each year but also for each exporter and importer, proposing the triple-indexed gravity model. Lastly, Egger (2000), and Egger and Pfaffermayr (2003) removed another restriction by adding bilateral interaction fixed effects to the mode.

All of these additions and changes leads to the following gravity model:

$$
\begin{aligned}
M_{i j t} & =\lambda_{t}+\alpha_{i}+\gamma_{j}+\delta_{i j} \\
& \beta_{1} d_{i j}+\beta_{2 i} Y_{i t}+\beta_{2 j} Y_{j t}+\beta_{3 i} Y_{i t}+\beta_{3 j} Y_{j t}+ \\
& \beta_{4} \Delta e_{i j t}+\beta_{5 i} R_{i t}+\beta_{5 j} R_{j t} \\
& \beta_{9} S I M_{i j t}+\beta_{10} R F_{i j t}+u_{i j t}
\end{aligned}
$$

where Mijt is imports of country $i$ from $j$ at time $t . \lambda_{t}, \alpha_{i}, \gamma_{j}$, and $\delta_{i j}$ are year fixed effects, and the time-invariant importer and exporter country, and bilateral interaction fixed effects, respectively. $d_{i j}$ stands for distance importer country $i$ and exporter country $j .{ }^{3}$ GDPs of importer and exporter countries, $Y_{i t}$ and $Y_{j t}$, their per capita GDPs, $y_{i t}$ and $y_{j t}$, as well as the real exchange rate $\Delta$ eijt and their foreign currency reserves, $R_{i t}$ and $R_{j t}$ are some of the other variables in the model.

Two variables in the model come from the competing trade theories: Considering the implications of the Increasing Returns Theory, similarity in economic sizes, $S I M_{i j t}$, is added to the model.

$$
S I M_{i j t}=\ln \left(1-\left(\frac{Y_{i t}}{Y_{i t}+Y_{j t}}\right)^{2}-\left(\frac{Y_{j t}}{Y_{i t}+Y_{j t}}\right)^{2}\right)
$$

captures the similarity in size of countries $i$ and $j$ at time $t$ in terms of their GDP. When the two countries are of equal size, the term inside the parentheses takes the value of 0.5 , and it decreases as countries diverge in size.

Consequently, a measure of relative factor endowments, $R F_{i j t}$, enters into the model because of the Heckscher-Ohlin Theory.

${ }^{3}$ This variable was omitted in both Egger (2000) and Egger and Pfaffermayr (2003), arguing that its effects were captured by the time-invariant bilateral interaction fixed effect. 


$$
R F_{i j t}=\left|\ln \left(\frac{K_{i t}}{L_{i t}}\right)-\ln \left(\frac{K_{j t}}{L_{j t}}\right)\right|
$$

gives the distance between the partner countries in terms of relative factor endowments. $K_{i t}$ and $L_{i t}$ denote the capital stock and the labor force for country $i$ at time $t$, respectively. When countries $i$ and $j$ have the same factor endowment ratios, this measure takes the value of zero, and it increases as the difference widens. Capital stocks needed for the above measure can be obtained using the perpetual inventory method as follows:

$$
\begin{gathered}
K_{i 1}=5\left(G F C F_{i 0}+G F C F_{i 1}\right) \\
K_{i t}=0.9 K_{i t-1}+G F C F_{i t}
\end{gathered}
$$

where $G F C F_{i t}$ is the gross fixed capital formation in country $i$ at time $t$. Note that capital stocks are assumed to depreciate at a constant rate of $10 \%$.

\section{B. Components of imports fixed effects}

Within this context, this paper eliminates the restriction on different components of imports by allowing different coefficients for its inter-industry, vertical and horizontal intra-industry components. ${ }^{4}$ Inter-industry imports result from different factor endowments and the resulting specialization of countries in different industries as predicted by the Heckscher-Ohlin trade models. On the other hand, intra-industry imports are reciprocal in the same industry. The Increasing Returns Trade Theory suggests the role of similarity between trading partners as its primary determinant. Intra-industry imports consist of significantly different parts. Horizontal intra-industry imports occur when similar products are simultaneously imported by both partners, mainly due to product differentiation and increasing returns to production. In contrast, vertical intra-industry imports are defined by Grubel and Lloyd (1975) as the simultaneous imports of goods in the same industry but at different stages of production by both partners. These result from vertical disintegration of production due to varying factor intensities within an industry.

Especially in the context of trade creation and diversion, separate consideration of different components of imports is important. Any increase in horizontal intra-

${ }^{4}$ In fact, Greenaway et al. (1995) demonstrate that a failure to separate horizontal and vertical imports can negatively impact the interpretation of empirical results. 
industry imports from a partner country due to lower tariff rates is not likely to replace imports from a non-partner country, since this only leads to imports of more varieties. Taste for variety assumption that is central in the Increasing Returns Theory suggests that consumers are not expected to give up varieties from a country in order to consume varieties from another. In other words, in this component of imports more creation is expected than diversion.

More creation and less diversion are also expected from vertical intra-industry imports in comparison to inter-industry imports. A preferential liberalization agreement will reduce tariffs imposed by both partners, leading to more imports of intermediate products and more re-exports of the finished product, hence more vertical intra-industry imports result. However, in comparison to its horizontal intra-industry imports, vertical component is less creating and more diverting since factor differences play a role in the latter rather than consumer preferences. This increases the possibility of replacing the lowest-cost non-partner supplier by less efficient intermediate product suppliers in partner country.

Consumer preferences do not play as much critical role in inter-industry imports either. A finished product crosses the borders between two partners only once in inter-industry trade, whereas the product crosses the border first at an intermediate stage of production from one country to its partner, and then returns back as a finished product in vertical intra-industry imports. Hence, removal of trade barriers will have a less significant impact on inter-industry imports, leading to less trade creation and diversion.

Given these different expectations on welfare, decomposing imports into its components is critical. One method of decomposing intra-industry imports is based on the ratio of unit values of exports. Apart from methodological concerns about the use of unit values, this technique has been criticized by the randomness in the choice of the threshold ratio, which is used to determine whether all of the intraindustry imports in an industry are vertical or horizontal. The method used in this paper is developed directly from the definitions for each component of intraindustry imports. ${ }^{5}$ Unlike the unit values approach, this method allows the intraindustry imports in an industry to be partly horizontal partly vertical. It uses values of imports at two different levels of aggregation without any need for data on the quantity of imports. The higher level of aggregation defines industries, and the lower level of aggregation defines different products in each industry. ${ }^{6}$

${ }^{5}$ This method was previously used in Kandogan (2004). 
Using imports data at the higher level of aggregation, the total amount of intraindustry imports of country $i$ from $j$ in each industry $s$ at time $t\left(I I M_{i j t}^{s}\right)$ is computed by finding the amount of imports of country $i$ from $j\left(M_{i j t}^{s}\right)$ matched by imports of country $j$ from $i\left(M_{j i t}^{s}\right)$. The unmatched part of imports of country $i$ from $j$ in this industry is inter -industry imports $\left(I N M_{i j t}^{s}\right)$, if there is any. Then, the sum of matched imports in each product $p$ of industry $s\left(M_{i j t}^{s p}\right)$ is computed using data at the lower level aggregation. This gives the imports of similar products in a sector, i.e. horizontal intra-industry imports of country $i$ from $j\left(H I I M_{i j t}^{s}\right)$. The rest of $I I M_{i j t}^{s}$ are the imports of different products within industry $s$, i.e. vertical intra industry imports of country $i$ from $j\left(V_{I I M}^{s}{ }_{i j t}\right)$, if there is any:

$$
\begin{aligned}
& I I M_{i j t}=\frac{1}{2} \sum_{s} I I M_{i j t}^{s}=\frac{1}{2} \sum_{s} M_{j i t}^{s}+M_{i j t}^{s}-\left|M_{j i t}^{s}-M_{i j t}^{s}\right| \\
& I N M_{i j t}= \begin{cases}\sum_{s} I N M_{i j t}^{s}=\sum_{s} M_{i j t}^{s}-I I M_{i j t}^{s} & \text { if positive } \\
0 & \text { otherwise }\end{cases} \\
& H I I M_{i j t}=\frac{1}{2} \sum_{s} H I I M_{i j t}^{s}=\frac{1}{2} \sum_{s} \sum_{p} M_{j i t}^{s p}+M_{i j t}^{s p}-\left|M_{j i t}^{s p}-M_{i j t}^{s p}\right| \\
& V_{I I M_{i j t}}= \begin{cases}\sum_{s} V I I M_{i j t}^{s}=\sum_{s} I I M_{i j t}^{s}-H I I M_{i j t}^{s} & \text { if positive } \\
0 & \text { otherwise }\end{cases}
\end{aligned}
$$

\section{Methodology}

The methodology to capture trade creation and diversion effects is based on analyzing the changes in error terms for different components of imports for member and non-member countries of blocs using the following gravity model:

\footnotetext{
${ }^{6}$ When decomposing imports into its components, the 4-digit level is used to define products, and the 2digit level for industries: A scrutiny of category definitions in each level reveal that 5-digit level lists varieties of basically the sample product, and 3-digit level is too aggregated and includes more than one product under one category.
} 


$$
\begin{aligned}
\left\{\begin{array}{c}
I N M_{i j t} \\
\left.\operatorname{VIIM}_{i j t}\right\} \\
\operatorname{HIIM}_{i j t}
\end{array}\right\} & =M_{i j t}^{m}=\lambda_{t}+\alpha_{i}+\gamma_{t}+\mu^{m}+\delta_{i j}^{m}+\phi_{i j t}^{m} \\
& \beta_{1} d_{i j}+\beta_{2 i} Y_{i t}+\beta_{2 j} Y_{j t}+\beta_{3 i} y_{i t}+\beta_{3 j} y_{j t}+ \\
& \beta_{4} \Delta e_{i j t}+\beta_{5 i} R_{i t}+\beta_{5 j} R_{j t}+ \\
& \beta_{6} C \beta_{i j}+\beta_{7} C L_{i j}+\beta_{8} C O L_{i j}+ \\
& \beta_{9} S I M_{i j t}+\beta_{9}^{I I M} S I M_{i j t .} D^{I I M}+\beta_{9}^{H I I M} S I M_{i j t .} D^{H I I M}+ \\
& \beta_{10} R F_{i j t}+\beta_{10}^{I I M} R F_{i j t .} D^{I I M}+\beta_{10}^{H I I M} R F_{i j t .} D^{H I I M}
\end{aligned}
$$

where $M_{i j t}^{m}$ component $m$ of country $i$ 's imports from country $j$ at time $t$. Two fixed effects are added to the triple-indexed model in Eq. (1): $\mu^{m}$ is the fixed for component $m$ of imports, and $\delta_{i j}^{n}$ is the time-invariant bilateral interaction fixed effects are computed for each component of imports rather than for overall imports of country $i$ from $j$. Lastly, the error term, $\phi_{i j t}^{m}$, is time-variant bilateral effect for component $m$ of country $i$ 's imports from $j$.

Unlike Egger (2000) or Egger and Pfaffermayr (2003), a distinction is made here between the importer and exporter in the computation of bilateral effects, since this allows for analysis of non-reciprocal trade agreements. Some bilateral factors that are typically used in the literature are also controlled: These are $C B_{i j}$, $C L_{i j}$, and $C O L_{i j}$, which capture the effects of common border, common language and past colonial relations, respectively ${ }^{7}$.

Lastly, given the theoretical implications of the Hechscher-Ohlin and the Increasing Returns Theories, variables of similarity in size and relative factor endowment differences are interacted with dummy variables for components of imports since these variables impact each component differently. While similarity in economic size increases both horizontal and vertical components of intraindustry imports, it decreases the inter-industry imports according to the Increasing Returns Theory. On the other hand, the Heckscher-Ohlin predicts a positive impact of relative factor endowment differences on inter-industry imports, and negative impacts on both components of intra-industry imports. $D^{I I M}$ takes the value of 1 if imports are intra-industry, and $D^{H I I M}$ takes the value of 1 if imports are horizontal

${ }^{7}$ Of course, one might think of other factors outside the literature's findings that affect the bilateral trade, but the methodology is based on the analysis of changes in the magnitude of bilateral effects. Therefore, it is not affected by other time-invariant bilateral factors. 
intra-industry.

This gravity equation is used to benchmark normal levels of imports and the deviations from the normal captured by these time-varying bilateral error terms are then used to compute trade creation and diversion effects. To get a better idea about welfare implications, when reporting the results these bilateral effects are divided by the GDP of the importer country. These ratios are summed before and after a liberalization agreement, and averaged over the number of years in these two periods. The changes in these average annual deviations from normal imports level relative to the GDP with partner and non-partner countries are examined to determine the size of trade creation and diversion, respectively.

\section{Regression models for testing the theory}

Regression analysis is used to test for the Natural Trade Partners Theory. Each observation in this analysis will come from importer and exporter country pairs for different preferential agreements. If the importer and exporter countries are partners in an agreement, the deviations from normal level of imports before and after the liberalization are compared to compute the amount of creation from the exporter partner country. If the importer country is a partner in an agreement but the exporter is not, the deviations before and after liberalization are compared to compute the amount of diversion from the exporter non-partner country. Hence, each observation either gives the amount of trade creation or diversion. Therefore, there will be two separate regression models analyzing the variation in each.

The Theory states that if two countries are natural partners, there will be more trade creation, and less trade diversion, making welfare gains the likely outcome of a preferential liberalization agreement between them. In the literature, there are competing definitions of what makes two countries natural partners. Geographically close countries, or those that have high initial trade volumes, or those that are complement of each other can be called natural partners. While distance between economic centers is used to measure the degree of naturalness according to the first definition, average of share of imports in importer's GDP in the three years preceding an agreement is used for the second. Schiff (1999) defines complementarity as the case where one country tends to import what the other exports. Two variables from two main trade theories that explain trade patterns are used to capture complementarity. These are difference in relative factor endowments (capital-labor ratio) from the Heckscher-Ohlin Theory, and similarity in income from the Increasing Returns Trade Theory. 
The Natural Trade Partners Theory's implications on the extent of diversion are based on distance, initial trade volume, and complementarity between partners in a preferential agreement. Hence, the implications of these between a partner and a non-partner on diversion need to be clarified within this context. If the non-partner in an agreement is actually a natural partner of the importer country, then diversion would be larger, since the preferential agreement is made against this natural partner. Hence, an extended version of the Natural Trade Partners Theory would predict the diversion to be larger, if the countries are geographically closer, or if they have high initial trade volume or if they complement each other.

The first set of regressions is rather simple. No effort is made to control for other factors, and creation and diversion in different components of imports are aggregated for country pairs:

$$
\left[\begin{array}{c}
T C_{i j a} \\
T D_{i j a}
\end{array}\right]=\sigma+\beta_{1} x_{i j a}+\varepsilon_{i j a} \quad \text { where } x_{i j a}=\left\{\begin{array}{c}
d_{i j} \\
M_{i j a} / Y_{i a} \\
S I M_{i j a} R F_{i j a}
\end{array}\right\}
$$

where $T C_{i j a}$, and $T D_{i j a}$ are creation and diversion between an importer $i$ and exporter $j$ resulting from an agreement $a . x_{i j a}$ is the measure of naturalness according to different definitions. It can be the distance, $d_{i j}$, share of initial imports in importer's GDP, $M_{i j a} / Y_{i a}$ or it could be similarity, $S I M_{i j a}$, or relative factor endowment differences, $R F_{i j a}$.

In the second set of regressions, other factors that would impact the degree of trade creation and diversion are also controlled with the help of importer and exporter country, and preferential agreement fixed effects. Initial tariff rates and other importer country idiosyncrasies are controlled using the importer country fixed effect. Competitiveness of partners and non-partners are controlled by the exporter country fixed effects along with their other relevant characteristics. Lastly, agreement fixed effects captures differences in intensity and degree of implementation:

$$
\left[\begin{array}{c}
T C_{i j a} \\
T D_{i j a}
\end{array}\right]=\sigma+\alpha_{i}+\gamma_{j}+\delta_{a}+\beta_{1} x_{i j a}+\varepsilon_{i j a}
$$

where $\alpha_{i}$ and $\gamma_{j}$ are the importer and exporter country fixed effects, and $\delta_{a}$ is the agreement fixed effect. 
Figure 1. Gravity regression results

$$
\begin{aligned}
& \left\{\begin{array}{l}
I N M_{i j t} \\
V I I M_{i j t} \\
H I I M_{i j t}
\end{array}\right\}=M_{i j t}^{m}=\lambda_{t}+\alpha_{i}+\gamma_{j}+\mu^{m}+\delta_{i j}^{m}+\phi_{i j t}^{m}+ \\
& -1.187 \boldsymbol{d}_{i j}+0.349 \boldsymbol{Y}_{i t}+0.074 \boldsymbol{Y}_{j t}+0.630 \boldsymbol{y}_{i t}+0.816 \boldsymbol{y}_{j t}+ \\
& \begin{array}{lllll}
(-105) & (19.83) & \text { (3.66) } & \text { (27.7) }
\end{array} \\
& -0.00001 \Delta \boldsymbol{e}_{i j t}+0.072 \boldsymbol{R}_{i t}+0.105 \boldsymbol{R}_{j t}+ \\
& \begin{array}{lll}
(-1.82) \quad(13.1) \quad(16.7)
\end{array} \\
& 0.252 \boldsymbol{C B}_{i j}+0.392 \boldsymbol{C L}_{i j}+0.790 \mathrm{COL}_{i j}+ \\
& \text { (10.0) (28.2) (29.6) } \\
& 0.043 \text { SIM }_{i j t}+0.187 \text { SIM }_{i j t} . D^{I I M}+0.016 \text { SIM }_{i j t} . D^{\text {HIM }}+ \\
& -0.070 \boldsymbol{R} \boldsymbol{F}_{i j t}-0.182 \boldsymbol{R} \boldsymbol{F}_{i j t} . \boldsymbol{D}^{I M}-0.196 \boldsymbol{R} \boldsymbol{F}_{i j t} . \boldsymbol{D}^{H I M} \\
& \begin{array}{lll}
(-10.9) \quad(-25.8) & (-26.1)
\end{array}
\end{aligned}
$$

Data Sources: GDP, capital and labor data from World Development Indicators 2004, exchange rate and foreign currency reserves data from IMF International Financial Statistics, trade data from UN COMTRADE, distance data from CEPII.

Lastly, creation and diversion in different components of imports are considered separately in the following model:

$$
\left[\begin{array}{l}
T C_{i j a} \\
T D_{i j a}
\end{array}\right]=\sigma+\alpha_{i}+\gamma_{j}+\delta_{a}+\mu^{m}+\beta_{1} x_{i j a}+\left[\begin{array}{ll}
\beta_{3}^{I I M} & \beta_{3}^{H I I M}
\end{array}\right] \cdot x_{i j a}\left[\begin{array}{c}
D^{I I M} \\
D^{H I I M}
\end{array}\right]+\varepsilon_{i j a}
$$

Note that separate constants, $\mu^{m}$, are allowed for different components of creation and diversion to see if they vary across components. Furthermore, naturalness variables are interacted with dummy variables for different components to see if their impacts vary across components. Although no pre-existing expectation exists for different effects of distance or initial imports across different components, the complementarity variables' effects are expected to vary (Kandogan, 2003). This further stresses the importance of decomposing creation and diversion effects for each component. While similarity is expected to increase intra-industry imports between natural partners, especially its horizontal component, relative factor differences are expected to increase inter-industry 
imports, and have the opposite effect on intra-industry imports.

\section{Effects of RTAs in the Euro-Mediterranean}

Throughout history, the Euro-Mediterranean has been the most trade active region in the world, and today it is the region with most elaborate network of RTAs with differing intensity of liberalization. Liberalization efforts have picked up in the last decade: In 1994, the European Economic Community, which has been a customs union since 1957, formed the European Economic Area with the European Free Trade Area to liberalize the movement of goods, labor, and capital. The early 1990s also saw trade liberalization under the Europe Agreements with Central and East European countries, and the accession of Turkey to the European Community Customs Union. In the second half of the 1990s and early 2000s, the cooperation agreements of the mid-1970s were transformed to eventually create the Euro-Mediterranean Free Trade Area under Association Agreements with Tunisia, Israel, Palestine, Morocco, Jordan, Algeria, Lebanon, and Egypt. In addition to these multilateral agreements, there are also a number of bilateral free trade agreements signed in this region.

These RTAs differ in intensity, ranging from non-reciprocal preferential agreements to economic areas as can be seen from Table 1. Differences also exist in the relevant characteristics of the partners involved. For a sample of agreements, Table 2 gives the weighted distance of their economic centers to EU capitals, share

Table 1. Characteristics of PTAs in the Euro-Mediterranean region

\begin{tabular}{lcc}
\hline \multicolumn{1}{c}{ Agreement } & Year & Intensity \\
\hline European Economic Area (EEA) & 1994 & 1 \\
European Community Customs Union (ECCU) & 1957 & 2 \\
Customs Union with Turkey (CUTR) & 1996 & 2 \\
PTAs of the European Union (PTAEU) & $1973-2002$ & 3 \\
European Free Trade Area (EFTA) & 1960 & 3 \\
PTAs of the EFTA (PTAEFTA) & $1986-2002$ & 3 \\
Europe Agreements (EA) & $1992-1997$ & 3 \\
Central European Free Trade Area (CEFTA) & $1993-2003$ & 3 \\
Euro-Mediterranean Free Trade Area (EMFTA) & $1997-2003$ & 3 \\
Mediterranean Cooperation Agreements (MCA) & $1976-1977$ & 4 \\
\hline
\end{tabular}

Data Source: EU External Trade Commission

Notes: The following are used to denote intensity: 1: economic area, 2: customs union, 3: free trade agreement, 4: non-reciprocal preferential agreement 
Table 2. Some characteristics of the Euro-Mediterranean countries

\begin{tabular}{|c|c|c|c|c|c|c|c|}
\hline Country & $d_{i j}$ & Agreement & $M_{i j a} / Y_{i}$ & $Y_{i}$ & $K_{i} / L_{i}$ & $\tau_{I}$ & $G C I_{i}$ \\
\hline Belgium & 720 & EEA (1994) & 8.91 & 298.2 & 93.3 & 0.00 & 4.95 \\
\hline Luxembourg & 716 & EEA (1994) & N.A. & 25 & 158.0 & 0.00 & 4.95 \\
\hline Netherlands & 765 & EEA (1994) & 9.53 & 461.4 & 87.2 & 0.00 & 5.30 \\
\hline France & 775 & EEA (1994) & 4.20 & 1654 & 84.4 & 0.01 & 4.92 \\
\hline Germany & 890 & EEA (1994) & 1.86 & 2271 & 90.2 & 0.00 & 5.28 \\
\hline Italy & 1132 & EEA (1994) & 2.92 & 1552 & 70.3 & 0.01 & 4.27 \\
\hline The UK & 844 & EEA (1994) & 4.83 & 1664 & 58.3 & 0.00 & 5.30 \\
\hline Ireland & 1194 & EEA (1994) & 12.28 & 117 & 73.4 & 0.00 & 4.90 \\
\hline Denmark & 1026 & EEA (1994) & 6.99 & 167.7 & 87.0 & 0.00 & 5.66 \\
\hline Greece & 1921 & EEA (1994) & 13.32 & 212.2 & 41.7 & 0.05 & 4.56 \\
\hline Spain & 1400 & EEA (1994) & 6.53 & 885.5 & 58.7 & 0.01 & 5.00 \\
\hline Portugal & 1782 & EEA (1994) & 17.04 & 182.3 & 38.9 & 0.01 & 4.96 \\
\hline Austria & 993 & EEA (1994) & 7.66 & 245.5 & 101.1 & 1.21 & 5.20 \\
\hline Finland & 1776 & EEA (1994) & 5.34 & 141.7 & 82.4 & 0.97 & 5.95 \\
\hline Sweden & 1468 & EEA (1994) & 6.88 & 238.1 & 76.4 & 0.95 & 5.72 \\
\hline Iceland & 2482 & EEA (1994) & 19.19 & 8.7 & 78.3 & 1.28 & 5.44 \\
\hline Norway & 1373 & EEA (1994) & 12.51 & 161.6 & 111.4 & 0.69 & 5.56 \\
\hline Switzerland & 790 & EEA (1994) & 9.85 & 239.8 & 118.8 & 0.79 & 5.49 \\
\hline The Czech Rep.* & 880 & EA (1992) & 2.47 & 160.5 & 21.6 & 2.79 & 4.55 \\
\hline The Slovak Rep.* & 1031 & EA (1992) & 2.10 & 72.3 & 17.9 & 2.79 & 4.43 \\
\hline Slovenia* & 979 & EA (1997) & 20.18 & 36.9 & 35.4 & 3.45 & 4.75 \\
\hline Hungary* & 1147 & EA (1992) & 9.40 & 139.7 & 16.9 & 10.74 & 4.56 \\
\hline Poland* & 1229 & EA (1992) & 9.26 & 426.7 & 11.6 & 15.50 & 3.98 \\
\hline Estonia* & 1718 & EA (1995) & 18.77 & 17.4 & 14.8 & 0.19 & 5.08 \\
\hline Latvia* & 1554 & EA (1995) & 12.14 & 23.8 & 7.1 & 1.58 & 4.43 \\
\hline Lithuania* & 1531 & EA (1995) & 10.01 & 40.2 & 13.0 & 1.20 & 4.57 \\
\hline Bulgaria & 1593 & EA (1993) & 9.18 & 57.1 & 7.4 & 5.66 & 3.98 \\
\hline Romania & 1684 & EA (1993) & 8.31 & 154.4 & 7.8 & 5.41 & 3.86 \\
\hline Cyprus* & 2721 & PTAEU (1973) & 6.32 & 8.9 & 36.2 & 5.42 & 4.56 \\
\hline Malta* & 1704 & PTAEU (1971) & 27.89 & 7.1 & 45.2 & 12.90 & 4.79 \\
\hline Turkey & 2040 & CUTR (1996) & 11.56 & 455.3 & 10.0 & 1.56 & 3.82 \\
\hline FYR Macedonia & 1524 & PTAEU (2001) & 20.42 & 13.8 & 7.3 & 4.56 & 3.34 \\
\hline Croatia & 1049 & PTAEU (2002) & 20.01 & 47.1 & 14.4 & 4.75 & 3.94 \\
\hline Egypt & 3004 & MCA (1977) & 16.95 & 294.3 & 4.5 & 20.11 & 3.88 \\
\hline Algeria & 1531 & EMFTA (2002) & 8.65 & 194.3 & 12.4 & 17.88 & 3.67 \\
\hline Israel & 3048 & EMFTA (2000) & 8.62 & 120.6 & 56.5 & 0.62 & 5.09 \\
\hline Jordan & 3133 & EMFTA (2002) & 19.42 & 23.6 & 10.5 & 5.66 & 4.58 \\
\hline Lebanon & 2957 & MCA (1977) & 1.03 & 17.8 & 15.1 & 14.60 & N.A. \\
\hline Morocco & 2075 & EMFTA (2000) & 19.49 & 128.3 & 5.1 & 13.89 & 4.06 \\
\hline Palestine & 3072 & EMFTA (1997) & N.A. & 1.7 & 7.3 & N.A. & N.A. \\
\hline Syria & 3038 & MCA (1977) & 18.14 & 58 & 5.7 & 10.78 & N.A. \\
\hline Tunisia & 1525 & EMFTA (1998) & 28.32 & 68.8 & 10.0 & 8.40 & 4.51 \\
\hline
\end{tabular}

Notes: Distances are weighted to EU capitals using their GDP, given in $\mathrm{km}$. Countries with * later joined the EU. GDP are estimated figures for 2003 in terms of purchasing power parity in billions of US\$. Capital-labor ratios are in thousands of US\$ per worker. GCI is the growth competitiveness index for 2004 by the World Economic Forum.

in GDP of pre-agreement imports volume from partners, the economic size measured by GDP, the capital-labor ratio of all countries of the region, and the initial tariff rates measured by average tariff revenue relative to imports volume as 
well as their competitiveness. These differences in agreements and partners are crucial in assessing the trade creation and diversion effects.

Results of the least squares regression of aggregate creation and diversion of imports are given in Table 3. The results do not show strong support for the Natural Trade Partners Theory no matter what definition is used for naturalness. In regressions for both creation, and diversion, the distance has the correct sign but it is insignificant. The share of initial imports in GDP has the incorrect sign. The theory has partial support when complementarity is used to define natural partners. Although the relative factor endowment differences variable has the correct sign and is significant, the similarity variable has the incorrect sign.

Table 3. Results of least squares regression

\begin{tabular}{cccc|ccc}
\hline & \multicolumn{3}{c|}{$T C_{i j}$} & \multicolumn{3}{c}{$T D_{i j}$} \\
\hline Const. & $2.4 .10^{-5}$ & 0.0014 & $-7.3 .10^{-4}$ & $7.6 .10^{-5}$ & $1.6 .10^{-4}$ & $-3.5 .10^{-5}$ \\
& $(0.01)$ & $(4.76)$ & $(-3.82)$ & $(0.22)$ & $(4.93)$ & $(-1.74)$ \\
$d_{i j}$ & $-2.1 .10^{-5}$ & & & $-3.4 .10^{-7}$ & & \\
& $(-0.05)$ & & & & \\
$M_{i j} / Y_{i}$ & & -0.2978 & & & -0.1007 & \\
& & $(-13.5)$ & & & $(-13.1)$ & \\
$S I M_{i j}$ & & & $-7.4 .10^{-4}$ & & & $-2.9 .10^{-5}$ \\
& & & $(-2.26)$ & & & $(-1.63)$ \\
$R F_{i j}$ & & & $6.2 .10^{-4}$ & & & $4.5 .10^{-5}$ \\
& & & $(6.12)$ & & & $(5.73)$ \\
Adj. $R^{2}$ & -0.001 & 0.108 & 0.009 & -0.001 & 0.014 & 0.001 \\
$F$ & 0.002 & 181.0 & 21.29 & 0.0001 & 172.6 & 8.494 \\
\hline
\end{tabular}

Notes: Given the high correlation among variables measuring naturalness, there is no regression that includes these simultaneously to avoid multicollinearity.

Table 4. Results of fixed effects regression

\begin{tabular}{cccc|ccc}
\hline & \multicolumn{3}{c|}{$T C_{i j}$} & \multicolumn{3}{c}{$T D_{i j}$} \\
\hline Const. & -0.0046 & -0.0093 & -0.0078 & -0.0033 & $1.4 .10^{-4}$ & $-3.4 .10^{-4}$ \\
& $(-0.61)$ & $(-1.61)$ & $(-3.23)$ & $(-3.36)$ & $(0.24)$ & $(-1.44)$ \\
$d_{i j}$ & $-3.7 .10^{-4}$ & & & $-4.5 .10^{-4}$ & & \\
& $(-0.66)$ & & $(-4.31)$ & & \\
$M_{i j} / Y_{i}$ & & -0.3903 & & & -0.1074 & \\
& & $(-14.1)$ & & & $(-10.2)$ & \\
$S I M_{i j}$ & & & -0.0026 & & & $-5.2 .10^{-4}$ \\
& & & $(-2.71)$ & & & $(-10.9)$ \\
$R F_{i j}$ & & 0.0010 & & & $3.0 .10^{-4}$ \\
& & & $(4.24)$ & & & \\
Adj. $R^{2}$ & 0.169 & 0.272 & 0.203 & 0.091 & 0.098 & 0.118 \\
$F$ & 4.528 & 7.464 & 13.57 & 6.918 & 7.382 & 20.23 \\
\hline
\end{tabular}


Fixed effects regression results are given in Table 4. In these regressions, factors other than those that define naturalness according to the literature are controlled with country and agreement fixed effects. Overall, the results are more significant. $\mathrm{T}$ statistics are higher, so are the adjusted $\mathrm{R}^{2}$ and $\mathrm{F}$ statistics. While distance becomes significant in the diversion regression, it is still insignificant in creation regression. However, only one of the variables of complementarity is still significant, and the share of initial imports in GDP still has the correct sign and is significant.

Table 5. Results of fixed effects regression on components

\begin{tabular}{|c|c|c|c|c|c|c|}
\hline \multirow{3}{*}{ Const. } & \multicolumn{3}{|c|}{$T C_{i j}$} & \multicolumn{3}{|c|}{$T D_{i j}$} \\
\hline & -0.0077 & -0.0031 & -0.0088 & -0.0023 & $1.3 .10^{-4}$ & $-5.2 .10^{-4}$ \\
\hline & $(-2.73)$ & $(-1.78)$ & $(-3.59)$ & $(-5.86)$ & $(0.56)$ & $(-2.19)$ \\
\hline$d_{i j}$ & $\begin{array}{c}5.4 .10^{-4} \\
(2.13)\end{array}$ & & & $\begin{array}{c}2.8 .10^{-4} \\
(7.20)\end{array}$ & & \\
\hline$d_{i j .} D^{I I M}$ & $\begin{array}{c}-7.9 .10^{-4} \\
(-2.52)\end{array}$ & & & $\begin{array}{c}-1.3 .10^{-4} \\
(-3.98)\end{array}$ & & \\
\hline$d_{i j .} D^{H I I M}$ & $\begin{array}{c}-0.0012 \\
(-3.81)\end{array}$ & & & $\begin{array}{c}-1.9 .10^{-4} \\
(-5.85)\end{array}$ & & \\
\hline$M_{i j} / Y_{i}$ & & $\begin{array}{l}-0.463 \\
(-42.3)\end{array}$ & & & $\begin{array}{l}-0.238 \\
(-53.1)\end{array}$ & \\
\hline$M_{i j} / Y_{i} \cdot D h^{I I M}$ & & $\begin{array}{l}0.348 \\
(7.27)\end{array}$ & & & $\begin{array}{l}0.122 \\
(8.70)\end{array}$ & \\
\hline$M_{i j} / Y_{i} \cdot D^{H I I M}$ & & $\begin{array}{l}0.419 \\
(23.5)\end{array}$ & & & $\begin{array}{l}0.181 \\
(30.8)\end{array}$ & \\
\hline$S I M_{i j}$ & & & $\begin{array}{c}-0.0036 \\
(-3.37)\end{array}$ & & & $\begin{array}{l}-6.9 .10^{-4} \\
(-13.14)\end{array}$ \\
\hline $\operatorname{SIM}_{i j} \cdot D^{I I M}$ & & & $\begin{array}{c}0.0013 \\
(1.69)\end{array}$ & & & $\begin{array}{c}2.1 .10^{-4} \\
(5.26)\end{array}$ \\
\hline $\operatorname{SIM}_{i j} \cdot D^{H I M}$ & & & $\begin{array}{l}0.0016 \\
(2.06)\end{array}$ & & & $\begin{array}{c}3.3 .10^{-4} \\
(7.66)\end{array}$ \\
\hline$R F_{i j}$ & & & $\begin{array}{c}0.0018 \\
(6.76)\end{array}$ & & & $\begin{array}{c}4.0 .10^{-4} \\
(19.8)\end{array}$ \\
\hline$R F_{i j} \cdot D^{I I M}$ & & & $\begin{array}{c}-0.0013 \\
(-5.41)\end{array}$ & & & $\begin{array}{c}-1.5 .10^{-4} \\
(-8.03)\end{array}$ \\
\hline$R F_{i j} . D^{H I I M}$ & & & $\begin{array}{c}-0.0012 \\
(-5.24)\end{array}$ & & & $\begin{array}{c}-1.9 .10^{-4} \\
(-9.87)\end{array}$ \\
\hline$D^{I I M}$ & $\begin{array}{l}0.0071 \\
(3.07)\end{array}$ & $\begin{array}{c}-0.0010 \\
(-5.56)\end{array}$ & $\begin{array}{c}0.0026 \\
(4.34)\end{array}$ & $\begin{array}{c}-0.0012 \\
(-4.41)\end{array}$ & $\begin{array}{c}8.2 .10^{-5} \\
(3.15)\end{array}$ & $\begin{array}{c}-4.0 .10^{-4} \\
(-7.63)\end{array}$ \\
\hline$D^{H I I M}$ & $\begin{array}{c}0.011 \\
(4.53)\end{array}$ & $\begin{array}{c}-6.0 .10^{-4} \\
(-3.37)\end{array}$ & $\begin{array}{r}0.0031 \\
(6.89)\end{array}$ & $\begin{array}{c}-0.0018 \\
(-6.66)\end{array}$ & $\begin{array}{c}-1.9 .10^{-5} \\
(-0.71)\end{array}$ & $\begin{array}{c}-6.1 .10^{-4} \\
(-11.3)\end{array}$ \\
\hline $\operatorname{Adj} . R^{2}$ & 0.091 & 0.357 & 0.211 & 0.051 & 0.131 & 0.124 \\
\hline$F$ & 5.919 & 28.19 & 13.94 & 8.749 & 22.64 & 20.86 \\
\hline
\end{tabular}


Table 5 gives the result of fixed effect regressions for components of imports. Since creation and diversion of each component are considered separately, variables defining naturalness are also interacted with components in these regressions. Coefficients of dummy variables for components support the decision to consider the components separately. As expected, preferential liberalization creates more and diverts less of intra-industry imports, especially its horizontal component.

Different effects of each variable of naturalness on components of imports created or diverted are noteworthy. While preferential agreements with geographically closer partners create more intra-industry imports relative to interindustry imports, such agreements divert more intra-industry exports of neighboring non-partners than their inter-industry exports. There is support for the theory primarily for intra-industry imports, especially the horizontal component. In contrast to its predictions, preferential agreements have more impact on the interindustry exports of distant countries than their inter-industry exports.

The previously observed negative effect of share of initial imports in GDP is only on inter-industry imports. In contrast, the Natural Trade Partners Theory's predictions are observed for intra-industry imports components. As can be seen from both creation and diversion regressions, liberalization with a partner with high initial intra-industry imports creates more intra-industry imports, and it diverts intraindustry imports from non-partners with which the country had high initial imports.

The regression results on the coefficients of complementarity variables point out the need to decompose imports created and diverted into its components. As predicted by the Increasing Returns Theory, liberalization with a country of similar economic size creates mostly intra-industry imports and it diverts both of its components from non-partners of similar sizes. On the contrary, relative factor endowment differences have the trade creating and diverting effects on interindustry imports, less so on horizontal and vertical intra-industry imports.

\section{Conclusions}

Countries tend to prefer regionalism over multilateralism citing reasons such as it proceeds quicker; it is more efficient producing better results; and it is less risky. These issues have been discussed in Bhagwati (1991), Bhagwati and Panagariya (1996), and Winters (1996). This paper looked at the issue of regionalism versus multilateralism to see if the rationale for RTAs is supported by the data. In particular, if RTAs create more trade than they divert. 
The paper analyzed the historically active trade in the Euro-Mediterranean region to see if there is evidence for the Natural Trade Partners Theory. The paper analyzed the inter-industry, and horizontal and vertical intra-industry imports components separately, as suggested by the Increasing Returns and the HeckscherOhlin theories, using different definitions of "natural" partners.

Preliminary regressions on overall trade created and diverted did not find strong evidence of the Natural Trade Partners Theory independent of the measure of natural partners. However, different results are obtained once each component of trade is treated separately. Overall, the theory has support for only intra-industry imports when distance or share of initial imports in GDP is used to define naturalness. There is greater support for the theory when complementarity is used to define naturalness, as the components of imports created or diverted are also according to the predictions of both the Increasing Returns and Heckscher-Ohlin theories. In this respect, the results of the analysis also show the importance of decomposing changes in imports to find evidence for the Natural Trade Partners theory, which is otherwise insignificant.

Weak support for the Natural Trade Partners Theory points out to the real risk of creating fragmented markets without having net welfare gains for the partner countries involved in RTAs. Results suggest net benefits for the regional partners for intra-industry trade. This implies that net benefits are exclusive to RTAs with partners that are relatively wealthy and similar in factor endowments, seriously limiting the options for regional integration for many countries. Even with such partners, governments need to balance their regional aspirations with multilateral commitments. RTAs can complement multilateral liberalization but do not provide viable substitutes in many instances.

Received 11 March 2007, Accepted 29 October 2007

\section{References}

Alessandri, Piergiorgio, 2000. "European and Euro-Mediterranean Agreements: Some Simulation Analysis on the Effects of the EU Trade Policy" CESPRI Working Paper No. 110.

Balassa, Bela (1986). "The Determinants of Intra-Industry Specialization in the United States Trade." Oxford Economic Papers 38, 220-233.

Balassa, Bela, and Luc Bauwens (1987). "Intra-Industry Specialization in a Multi-Country and Multi-Industry Framework." The Economic Journal 97, 923-939. 
Baldwin, Richard (1994). Towards an Integrated Europe. Centre for Economic Policy Research, London.

Bayoumi, Tamim, and Barry Eichengreen (1995). "Is Regionalism Simply a Diversion? Evidence from the Evolution of the EC and EFTA.”NBER Working Paper 5283.

Bergstrand, Jeffrey (1985). "The Gravity Equation in International Trade: Some Microeconomic Foundations, and Empirical Evidence." Review of Economics and Statistics 67, 474-481.

Bhagwati, Jagdish (1991). The World Trading System at Risk, Hempstead: Harvester Wheatsheaf.

Bhagwati, Jagdish and Arvind Panagariya (1996). "Preferential Trading Areas and Multilateralism -Strangers, Friends or Foes?' In Bhagwati Jagdish and Arvind Panagariya (Eds.) The Economics of Preferential Trade Agreements, Washington DC: AEI Press.

Deardorff, Alan and Robert Stern (1994). "Multilateral Trade Negotiations and Preferential Trading Arrangements" In Deardorff Alan and Robert Stern (Eds.) Analytical and Negotiating Issues in the Global Trading Systems, Ann Arbor: University of Michigan Press.

Egger, Peter (2000). "A Note on the Proper Econometric Specification of the Gravity Equation." Economic Letters 66, 25-31.

Egger, Peter, and Michael Pfaffermayr (2003). "The Proper Panel Econometric Specification of the Gravity Equation: A Three Way Model with Bilateral Interaction Effects." Empirical Economics 28, 571-580.

Frankel, Jeffrey (1996). Regional Trading Blocs in the World Economic System, Washington DC: Institute of International Economics.

Frankel, Jeffrey, Ernesto Stein, and Shang-jin Wei (1995). "Trading Blocs and the Americas: The Natural, the Unnatural, and the Supernatural." Journal of Development Economics 47, 61-95.

Greenaway, David and Chris Milner (2002). "Regionalism and Gravity." Leverhulme Centre Research Paper 2002/20.

Greenaway, David, et al. (1995). "Vertical and Horizontal Intra-industry Trade: A Cross Country Analysis for the United Kingdom" Economic Journal 105(433), 1505-18.

Grubel, Herbert, and Peter Lloyd (1975). Intra-industry Trade: The Theory and Measurement of International Trade in Differentiated Products, London.

Helpman, Elhanan (1987). "Imperfect Competition and International Trade: Evidence from Fourteen Industrial Countries." Journal of Japanese and International Economics 1, 62-81.

Hoekman, Bernard, and Simeon Djankov (1996). "Catching Up with Eastern Europe? The European Union's Mediterranean Free Trade Initiative.” World Bank Policy Research Working Paper 1562.

Johnson, Harry (1962). Money, Trade and Economic Growth: Survey lectures in Economic Theory, Cambridge, Massachusetts: Harvard University Press.

Kandogan, Yener, 2003. "Intra-Industry Trade of Transition Countries: Trend and Determinants" Emerging Markets Review 4(3), 273-86. 
Krishna, Pravin (2003). “Are Regional Trading Partners "Natural”?" Journal of Political Economy 111, 202-226.

Krugman, Paul (1991). "The move to Free Trade Zones" In Symposium on Policy Implications of Trade and Currency Zones, Federal Reserve Bank of Kansas City.

Linneman, Hans (1966). "Trade Flows and Geographical Distance, or the Importance of Being Neighbors" In Bos H.C. (Ed.) Towards Balanced International Growth, Amsterdam: North Holland.

Lipsey, Richard (1960). "The Theory of Customs Unions: A General Survey" Economic Journal 70, 498-513.

Mathilde, Maurel, and Guillaume Cheikbossian (1998). "The New Geography of East European Trade", Kyklos 51, 45-71.

Matyas, Laszlo (1997). "Proper Econometric Specification of the Gravity Model." The World Economy 20, 363-368.

McMillan, John, and Ewen McCann (1981). "Welfare Effects in Customs Unions" Economic Journal 91, 697-703.

Meade, James (1955). The Theory of Customs Unions, Amsterdam: North Holland.

Panagariya, Arvind (1997). "Preferential Trading and the Myth of Natural Trading Partners" Japan and the World Economy 9, 471-489.

Polak, Jacques (1996). "Is APEC a Natural Regional trading Bloc? A Critique of the Gravity Model of International Trade." The World Economy 19, 533-543.

Poyhonen, Pentty (1963). "A Tentative Model for Volume in Trade between Countries." Weltwirtschaftliches Archiv 90, 91-113.

Schiff, Maurice (1997). "Small is Beautiful: Preferential Trade Agreements and the Impact of Country Size, Market Share, and Smuggling” Journal of Economic Integration 12(3), 359-387.

Schiff. Maurice (1999). "Will the Real "Natural Trading Partner" Please Stand Up?" World Bank, Development Research Department Working Paper.

Summers, Lawrence (1991). "Regionalism and the World Trading System" In Symposium on Policy Implications of Trade and Currency Zones, Federal Reserve Bank of Kansas City.

Thursby, Jerry and Marie Thursby (1987). "Bilateral Trade Flows, the Linder Hypothesis and Exchange Risk." Review of Economics and Statistics 69, 488-495.

Tinbergen, Jan (1962). Shaping the World Economy. Twentieth Century Fund, New York.

Viner, Jacob (1950). The Customs Union Issue. Carnegie Endowment for International Peace, New York.

Wang, Zhen Kun, and Alan Winters (1991). "The Trading Potential of Eastern Europe." CEPR Discussion Paper 610.

Winters, Alan (1996). "Regionalism versus Multilateralism" World Bank, Policy Research Working Paper 1687.

Wonnacott, Paul, and Mark Lutz (1989). "Is There a Case for Free Trade Areas?" In Schott, Jeffrey (Ed.), Free Trade Areas and US Trade Policy, 59-84. Washington DC: Institute of International Economics 


\section{Appendix 1. Euro-Mediterranean region's trading partners}

Angola, Antigua and Barbuda, Argentina, Armenia, Australia, Azerbaijan, Bahamas, Bahrain, Bangladesh, Barbados, Belarus, Belize, Benin, Bhutan, Bolivia, Bosnia Herzegovina, Botswana, Brazil, Burkina Faso, Burundi, Cambodia, Cameroon, Canada, Cape Verde, Central African Rep., Chad, Chile, China, Colombia, Comoros, Congo, Costa Rica, Cote d'Ivoire, Dem. Rep. of Congo, Djibouti, Dominica, Dominican Rep., Ecuador, El Salvador, Equatorial Guinea, Eritrea, Ethiopia, Fiji, FS Micronesia, Gabon, Gambia, Georgia, Ghana, Grenada, Guatemala, Guinea, Guinea-Bissau, Guyana, Haiti, Honduras, Hong Kong, India, Indonesia, Iran, Jamaica, Japan, Kazakhstan, Kenya, Korea, Kuwait, Kyrgyzstan, Lao People's Dem. Rep., Lesotho, Libya, Macao, Madagascar, Malawi, Malaysia, Maldives, Mali, Mauritania, Mauritius, Mexico, Moldova, Mongolia, Mozambique, Namibia, Nepal, New Zealand, Nicaragua, Niger, Nigeria, Oman, Pakistan, Panama, Papua New Guinea, Paraguay, Peru, Philippines, Russian Fed., Rwanda, Saint Lucia, Sao Tome and Principe, Saudi Arabia, Senegal, Seychelles, Sierra Leone, Singapore, South Africa, Solomon Islands, Somalia, Sri Lanka, Sudan, Suriname, Swaziland, Tajikistan, Tanzania, Thailand, Togo, Tonga, Trinidad and Tobago, Uganda, Ukraine, United Arab Emirates, Uruguay, USA, Uzbekistan, Vanuatu, Venezuela, Vietnam, Yemen, Zambia, and Zimbabwe. 